\title{
Dioxygen reactivity of meso-hydroxylated hemes: intermediates in heme degradation process catalyzed by heme oxygenase
}

\author{
SANKAR PRASAD RATH \\ Department of Chemistry, Indian Institute of Technology, Kanpur 208016 \\ e-mail: sprath@iitk.ac.in
}

\begin{abstract}
Heme oxygenase (HO) is the only enzyme in mammals known to catalyse the physiological degradation of unwanted heme into biliverdin, Fe ion and CO. The process involves introduction of the hydroxyl group at one of its meso-positions as the first fundamental step of the heme cleavage process. It was also found that meso-amino heme undergoes similar ring-cleavage process while reacting with dioxygen in presence of pyridine as an axial ligand. The present paper briefly reviews the reactions of model meso-hydroxylated heme and its analogues with dioxygen, and their relevance in the heme degradation process.
\end{abstract}

Keywords. Heme oxygenase; heme degradation; coupled oxidation; variable temperature paramagnetic NMR.

\section{Introduction}

Porphyrins are well documented for their stability towards oxidation. In particular, iron porphyrins are used biologically to carry out numerous oxidations with dioxygen and hydrogen peroxide where highly oxidized forms participate without undergoing porphyrin ring degradation. ${ }^{1}$ Considerable effort has been expended to detect and isolate the reactive iron porphyrins in highly oxidized states. ${ }^{1}$ However, to control the level of heme, Nature utilizes heme oxygenase (HO) which catalyses the physiological degradation of heme into biliverdin, $\mathrm{CO}$ (a potential neurotransmitter) and free iron in a reaction that requires $\mathrm{O}_{2}, \mathrm{NADPH}$ and cytochrome $\mathrm{P} 450$ reductase. ${ }^{2-6}$ It also provides a mechanism for the recovery and reutilization of the iron atom. This is important because only $1-3 \%$ of the iron utilized daily in the synthesis of red blood cells is obtained from the diet. The rest of the daily iron requirement is met by recycling the iron in the body, most of which is present in hemoglobin, myoglobin and other heme proteins.

Heme oxygenase (HO) is highly unusual since it uses heme as both its substrate and prosthetic group. Mammalian heme oxygenases are membrane-bound and are relatively difficult to purify and study. ${ }^{2-6}$ This makes investigation of the enzyme structure and mechanism difficult. The overall transformations of heme into biliverdin catalysed by heme oxygenase (HO) are shown in scheme $1 .^{2-6}$
Studies of the reaction mechanism were primarily carried out with a model coupled oxidation process

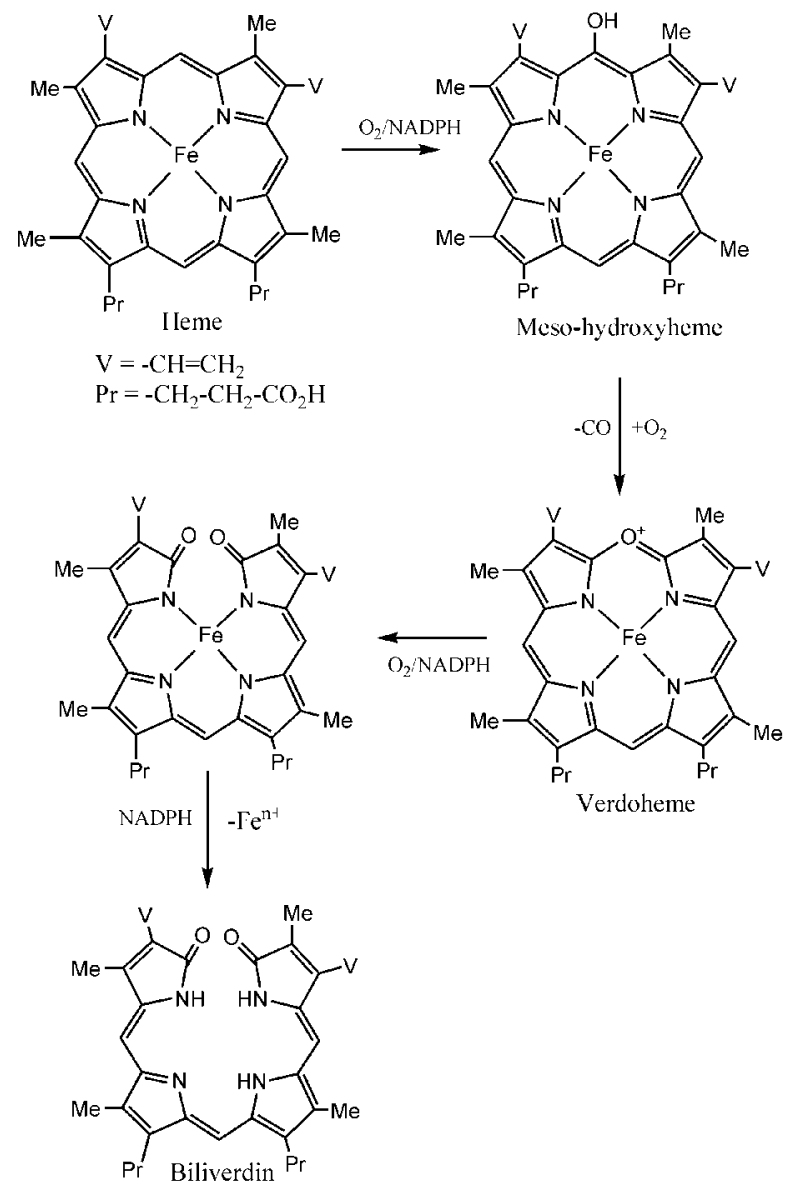

Scheme 1. 


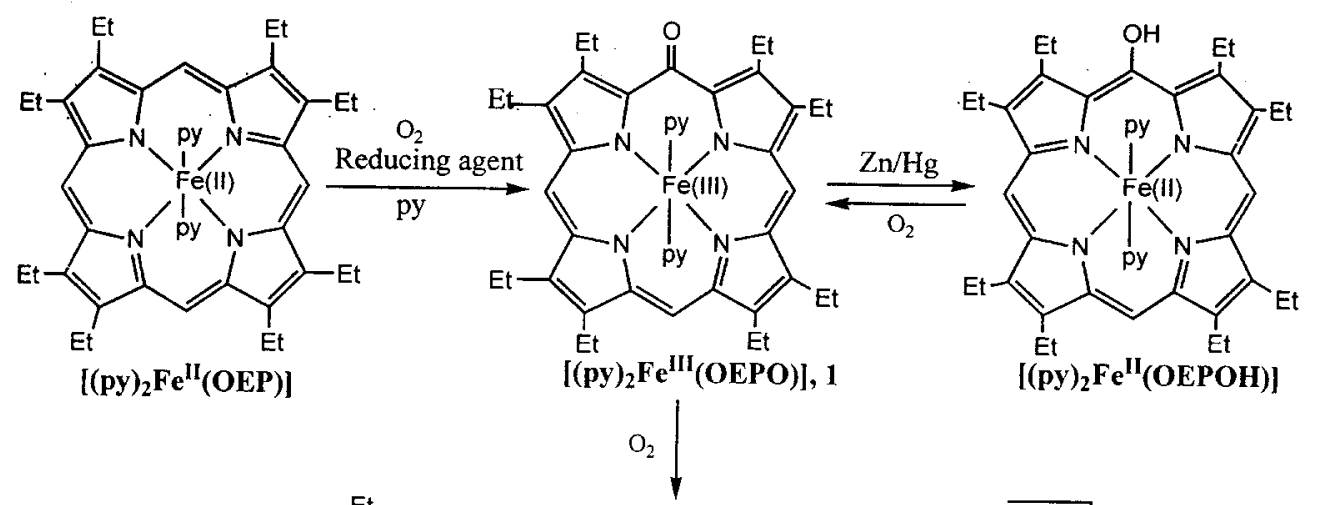

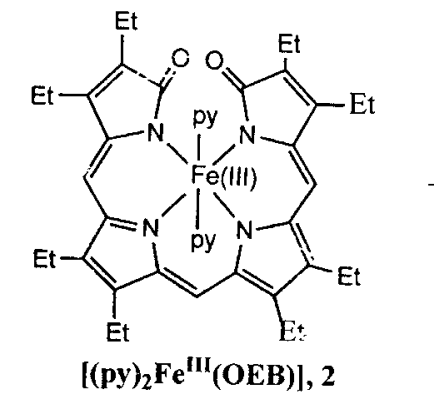

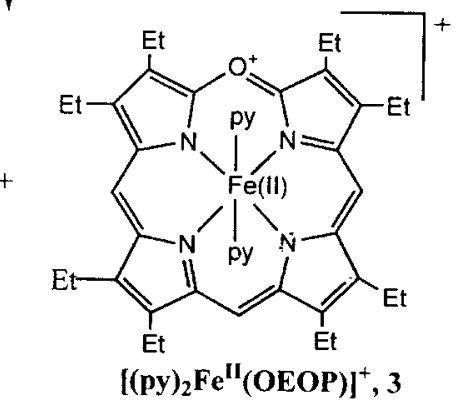

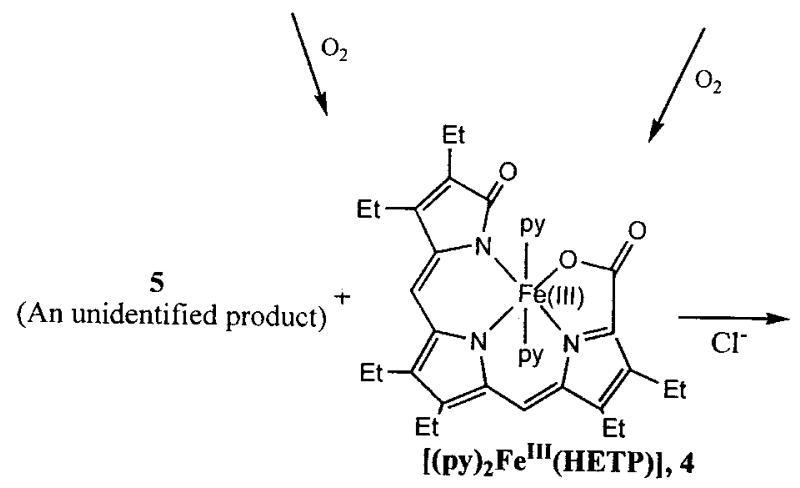

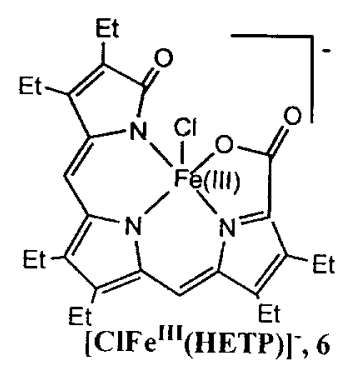

Scheme 2.

in which the HO-bound heme could be converted to verdoheme and biliverdin by ascorbic acid or hydrazine in the absence of NADPH and cytochrome $\mathrm{P} 450$ reductase via the formation of similar intermediates observed during the biological oxidation of heme by $\mathrm{HO}^{2-7}$ The process involves initial meso hydroxylation of the heme to form a reactive iron oxophlorin which is the fundamental step in the heme degradation process. The addition of an oxygen function at the meso-position of porphyrin results in an oxophlorin macrocycle with significantly different properties from the original porphyrin. ${ }^{7}$ The present paper briefly reviews the reactions of model meso-hydroxylated heme and its analogues with dioxygen in order to understand the electronic and geometrical requirements leading to heme degradation.

\section{Meso-hydroxylated hemes and its reaction with dioxygen}

The six-coordinate complex, [(py $\left.)_{2} \mathrm{Fe}^{\mathrm{III}}(\mathrm{OEPO})\right], \mathbf{1}$, as shown in scheme 2 , is a widely studied model in the heme-degradation process by either the coupled oxidation process or heme catabolism as mediated by heme oxygenase. ${ }^{7}$ This reactive molecule has been characterized by several spectroscopic methods including X-ray crystal structure of the molecule as shown in figure $1 .^{7-9}$ The porphyrin, in figure 1 , is almost planar with the pyridine ligands parallel to one another and $13.3^{\circ}$ away from the neighbouring $\mathrm{Fe}-\mathrm{N}$ bond. Also, it has been found that the nature of the axial ligand alters the distribution of electrons between the metal and the porphyrin within the complexe. ${ }^{8,10-13}$ 
Although $\left[(\mathrm{py})_{2} \mathrm{Fe}^{\mathrm{III}}(\mathrm{OEPO})\right], \mathbf{1}$, is sufficiently stable for isolation when handled carefully under dinitrogen atmosphere, it is also reactive in solution towards dioxygen where it undergoes a series of changes that have been followed by ${ }^{1} \mathrm{H}$ NMR spectroscopy as shown in figure $2 .{ }^{14}$ Trace A shows a portion of the paramagnetically shifted ${ }^{1} \mathrm{H}$ NMR spectrum of $\left[(\mathrm{py})_{2} \mathrm{Fe}^{\mathrm{III}}(\mathrm{OEPO})\right], \mathbf{1}$. The two prominent resonances arise from the two of the four chemically distinct methylene groups of $\mathbf{1}$ and the other methylene and methyl resonances occur in the crowded $0-10 \mathrm{ppm}$ range, whereas the meso resonances occurs far upfield. ${ }^{7-9}$ Upon addition of dry dioxygen, the spectrum converts to B after $4 \mathrm{~h}$. At this point, the resonances of $\mathbf{1}$ have vanished completely, while several new resonances have developed. The most intense of these are labelled 2 and are identified as belonging to $\left[(\mathrm{py})_{2} \mathrm{Fe}^{\mathrm{III}}(\mathrm{OEB})\right], \mathbf{2}$, while several other unidentified species are also present as seen in trace B. The formation of diamagnetic verdoheme 3 in the oxidation process cannot be seen in figure 2 , since it falls in the crowded diamagnetic region but its presence are detected through its characteristic UV-Vis spectrum. ${ }^{7,8}$ It has been also found that the pyridine solutions of octaethylverdoheme $\mathbf{3}$ can be converted to $\mathbf{2}$ by exposure to dioxygen. ${ }^{14}$

After one day, the spectrum $\mathrm{B}$ again changes to a completely new spectrum as shown in trace $\mathrm{C}$ of figure $2 .{ }^{14}$ This sample is stable on further exposure to dioxygen or air for several days. The pattern of resonances for 4 seen in trace $\mathrm{C}$ is consistent with the structure $\left[(\mathrm{py})_{2} \mathrm{Fe}^{\mathrm{III}}(\mathrm{HETP})\right], \mathbf{4}$, which shows six signals from six chemically distinct methylene groups and two meso protons of equal intensity. A minor signal at $81.2 \mathrm{ppm}$ in trace $\mathrm{C}$ of figure 2 corresponds to an unidentified product, $\mathbf{5}$.

Attempts to crystallize $\mathbf{4}$ directly from the pyridine solution have not been successful. However, upon addition of tetra ( $n$-butyl) ammonium chloride, a chloride-ligated species $\mathbf{6}$, as in scheme 2 , is formed whose anionic structure (counter cation $n-\mathrm{Bu}_{4} \mathrm{~N}^{+}$is not shown) is depicted in figure $3 .{ }^{14}$ The ${ }^{1} \mathrm{H}$ NMR spectrum of 6 in $\mathrm{CDCl}_{3}$ is shown in figure $4 .{ }^{14}$ The spectrum shows significant hyperfine shifts for the methylene protons and produces 10 resonances (two with twice the intensity) and also two equally intense meso resonances. The methyl resonances are found in the crowded diamagnetic region. However, 6 in pyridine- $d_{5}$ gives ${ }^{1} \mathrm{H}$ NMR spectrum that is identical to that of $\left[(\mathrm{py})_{2} \mathrm{Fe}^{\mathrm{III}}(\mathrm{HETP})\right], \mathbf{4}{ }^{14}$

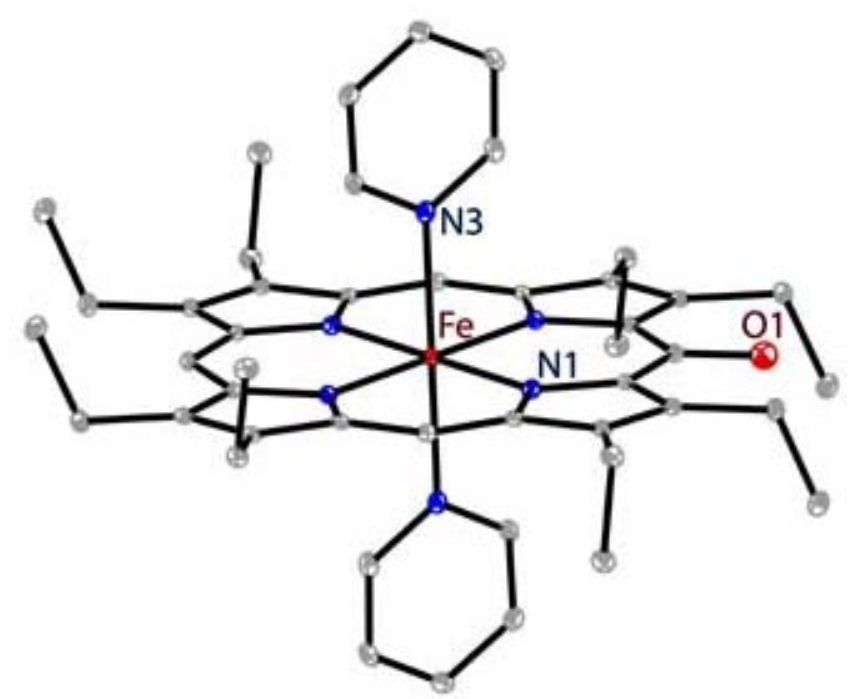

Figure 1. A perspective view of $\left[(\mathrm{Py})_{2} \mathrm{Fe}^{\mathrm{III}}(\mathrm{OEPO})\right]$ at $10 \mathrm{~K}$ showing $30 \%$ thermal contours. Taken from ref. [8].
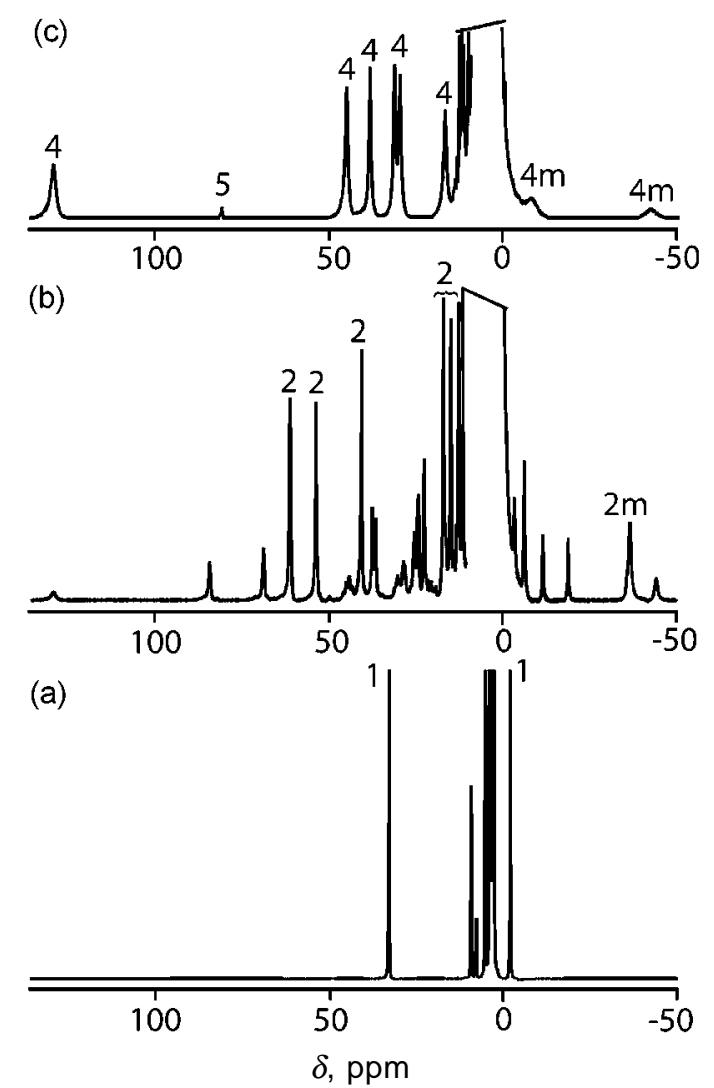

Figure 2. $500 \mathrm{MHz}{ }^{1} \mathrm{H}$ NMR spectrum of $\left[(\mathrm{py})_{2} \mathrm{Fe}\right.$ (OEPO)], $\mathbf{1}$, in pyridine- $d_{5}$ at $23^{\circ} \mathrm{C},(\mathbf{a})$ before addition of $\mathrm{O}_{2}$, (b) $4 \mathrm{~h}$ after exposure to $\mathrm{O}_{2}$, and (c) 1 day after exposure to $\mathrm{O}_{2}$. Resonances labelled 1 are assigned to the methylene resonances of $\left[(\mathrm{py})_{2} \mathrm{Fe}^{\mathrm{III}}(\mathrm{OEPO})\right], \mathbf{1}$, those labelled 2 and $2 \mathrm{~m}$ are assigned to the methylene and meso resonances of $\left[(\mathrm{py})_{2} \mathrm{Fe}^{\mathrm{III}}(\mathrm{OEB})\right], 2$ and those labelled 4 and $4 \mathrm{~m}$ are assigned to the methylene and meso resonances of $\left[(\mathrm{py})_{2} \mathrm{Fe}^{\mathrm{III}}(\mathrm{HETP})\right], 4$. Label 5 is assigned for $\mathbf{5}$. Taken from ref. [14]. 
Addition of reducing agents such as zinc amalgam, and hydrazine to the pyridine solution of $\left[(\mathrm{py})_{2} \mathrm{Fe}^{\mathrm{III}}\right.$ (OEPO)] under dinitrogen atmosphere produces a bright-red diamagnetic $\left[(\mathrm{py})_{2} \mathrm{Fe}^{\mathrm{II}}(\mathrm{OEPOH})\right]$ compound within a minute. ${ }^{12}$ Once exposed to dioxygen, the reduced species immediately converts again to $\left[(\mathrm{py})_{2} \mathrm{Fe}^{\mathrm{III}}(\mathrm{OEPO})\right]$ as shown in figure 5 and heme degradation starts after that. ${ }^{12}$ Scheme 2 summarizes all the transformations in the ring cleavage process as discussed.

\section{Meso-amino hemes}

In order to search for the reactive heme with composition $\left[(\mathrm{py}){ }_{2} \mathrm{Fe}^{\mathrm{II}}\right.$ (meso-R-OEP)] that undergoes heme degradation upon reaction with dioxygen, investigations were carried out taking various meso-R-substituted hemes. It was found that even when $\mathrm{R}=\mathrm{NH}_{2}$, heme degradation takes place. ${ }^{15,16} \mathrm{In}$ order to get more insight into this, the stable $\left[\mathrm{ClFe}{ }^{\mathrm{III}}\left(\right.\right.$ meso $-\mathrm{NH}_{2-}$

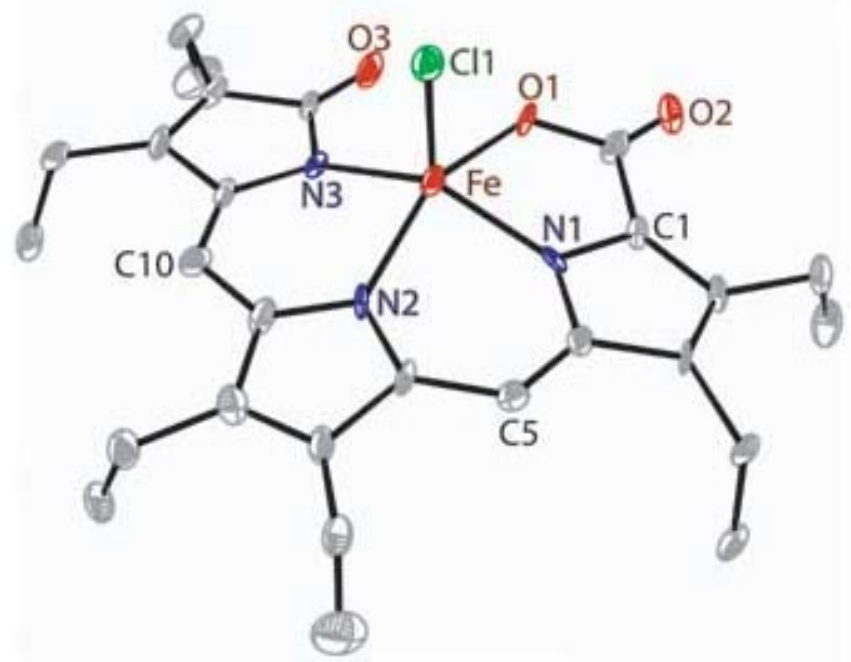

Figure 3. A perspective view of anion $\left[\mathrm{ClFe}^{\mathrm{III}}(\mathrm{HETP})\right]^{-}$, 6, showing $30 \%$ thermal contours. Counter cation $n-\mathrm{Bu}_{4} \mathrm{~N}^{+}$ and solvent molecules are omitted for clarity. Taken from ref. [14].

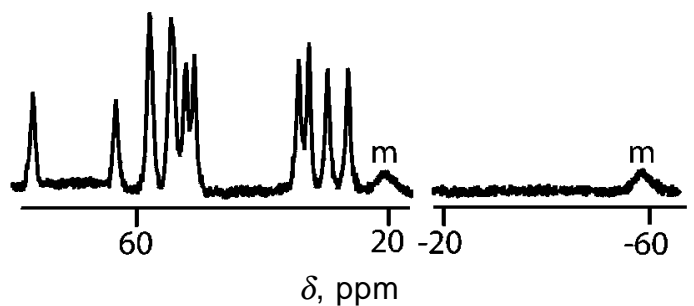

Figure 4. Portions of the $500 \mathrm{MHz}{ }^{1} \mathrm{H}$ NMR spectrum of 6 in $\mathrm{CDCl}_{3}$ at $23^{\circ} \mathrm{C}$. The meso proton resonances are labelled $m$, while other resonances are assigned to the methylene protons. Taken from ref. [14].
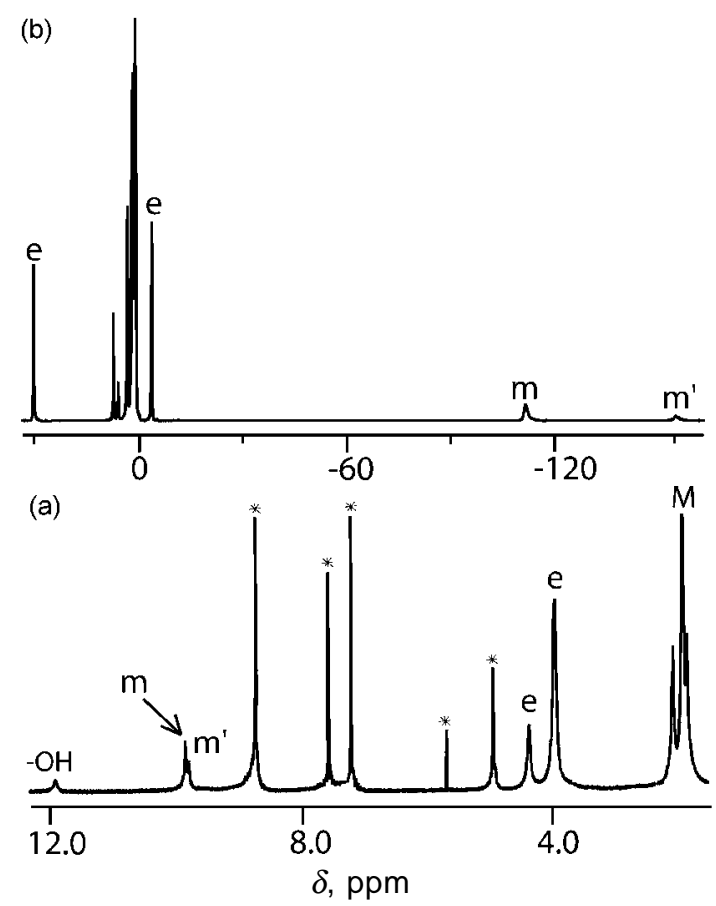

Figure 5. ${ }^{1} \mathrm{H}$ NMR spectrum of a pyridine- $d_{5}$ solution of $\left[(\mathrm{py})_{2} \mathrm{Fe}^{\mathrm{II}}(\mathrm{OEPOH})\right](\mathbf{a})$ before and $(\mathbf{b})$ after the addition of dioxygen. Taken from ref. [12].
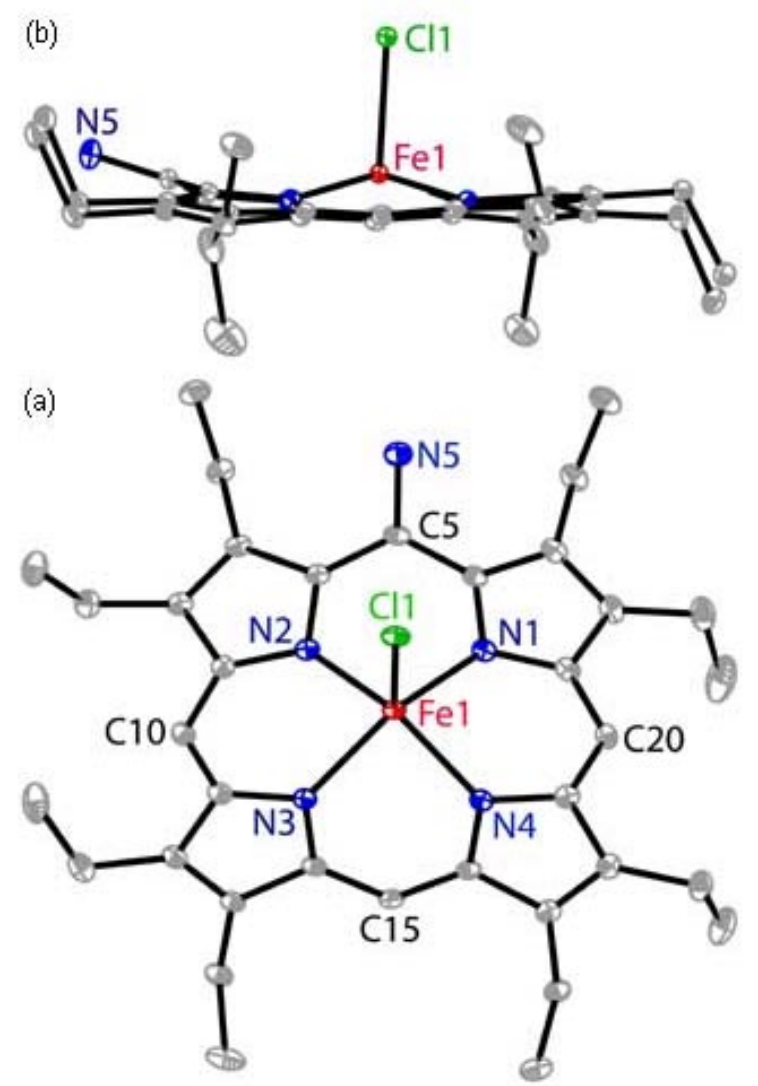

Figure 6. Two perspective views of $\left[\mathrm{ClFe}{ }^{\mathrm{III}}\left(\right.\right.$ meso- $-\mathrm{NH}_{2}-$ OEP)] showing $30 \%$ thermal contours. Taken from ref. [16]. 


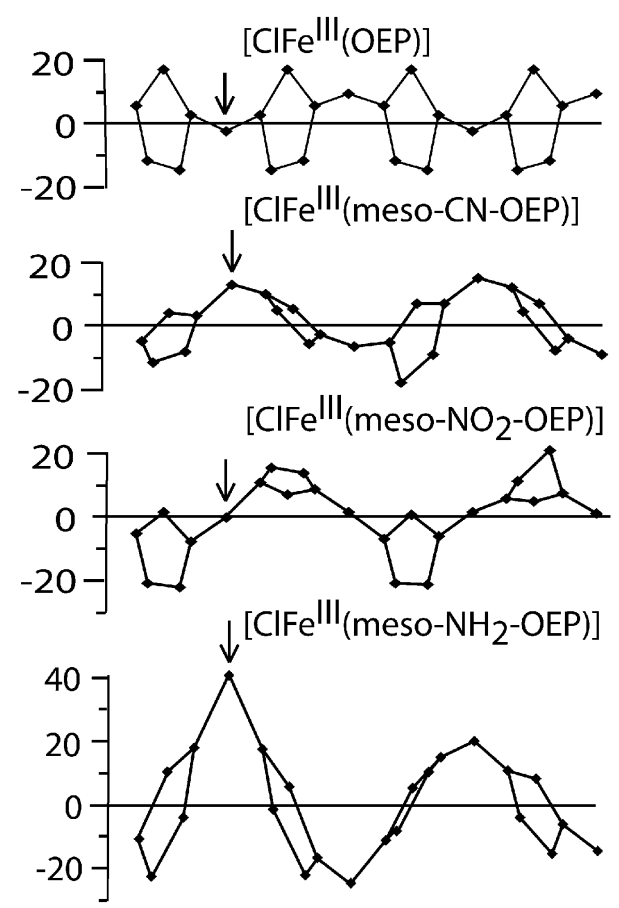

Figure 7. Out-of-plane displacements (in units of $0.01 \AA$ ) plot for the porphyrin core atoms from the mean plane of the porphyrin Meso substituents attached to the carbon atoms are denoted by arrows as shown on the top. Taken from ref. [16].
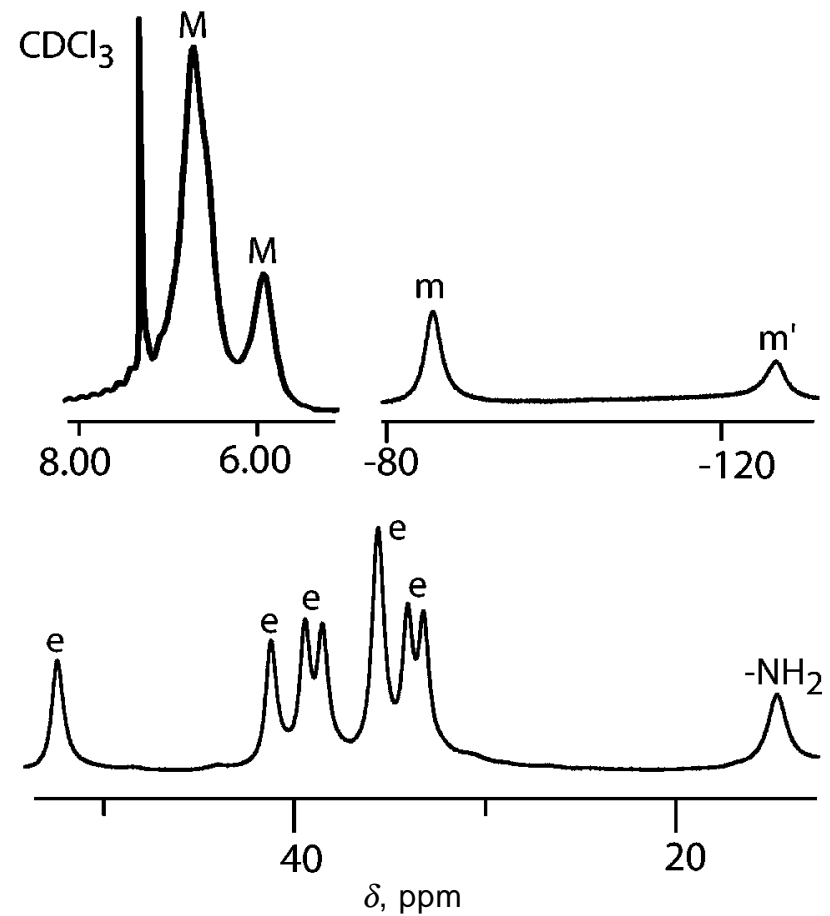

Figure 8. Portions of the $500 \mathrm{MHz}{ }^{1} \mathrm{H}$ NMR spectrum of $\left[\mathrm{ClFe}^{\mathrm{III}}\left(\right.\right.$ meso- $\left.\left.\mathrm{NH}_{2}-\mathrm{OEP}\right)\right]$ in chloroform-d at $25^{\circ} \mathrm{C}$. Resonances are labelled $\mathrm{m}$ and $\mathrm{m}^{\prime}$ for the meso protons, $\mathrm{M}$ for methyl protons, and e for the methylene protons. Taken from ref. [16].
OEP)] were synthesized and structurally characterized for thorough investigation.

$\mathrm{X}$-ray structure of $\left[\mathrm{ClFe}^{\mathrm{III}}\left(\right.\right.$ meso- $\left.\left.\mathrm{NH}_{2}-\mathrm{OEP}\right)\right]$ is shown in figure 6 where the porphyrin ring is unusually distorted. This is best appreciated by turning to figure 7 where the out-of-plane displacements (in units of $0 \cdot 01 \AA$ ) of the core atoms of $\left[\mathrm{ClFe}^{\mathrm{III}}\right.$ (meso$\mathrm{NH}_{2}$-OEP) $]$ are compared with those of $\left[\mathrm{ClFe}^{\mathrm{III}}\right.$ $(\mathrm{OEP})],\left[\mathrm{ClFe}^{\mathrm{III}}\right.$ (meso-NC-OEP)] and $\left[\mathrm{ClFe}^{\mathrm{III}}(\right.$ meso-
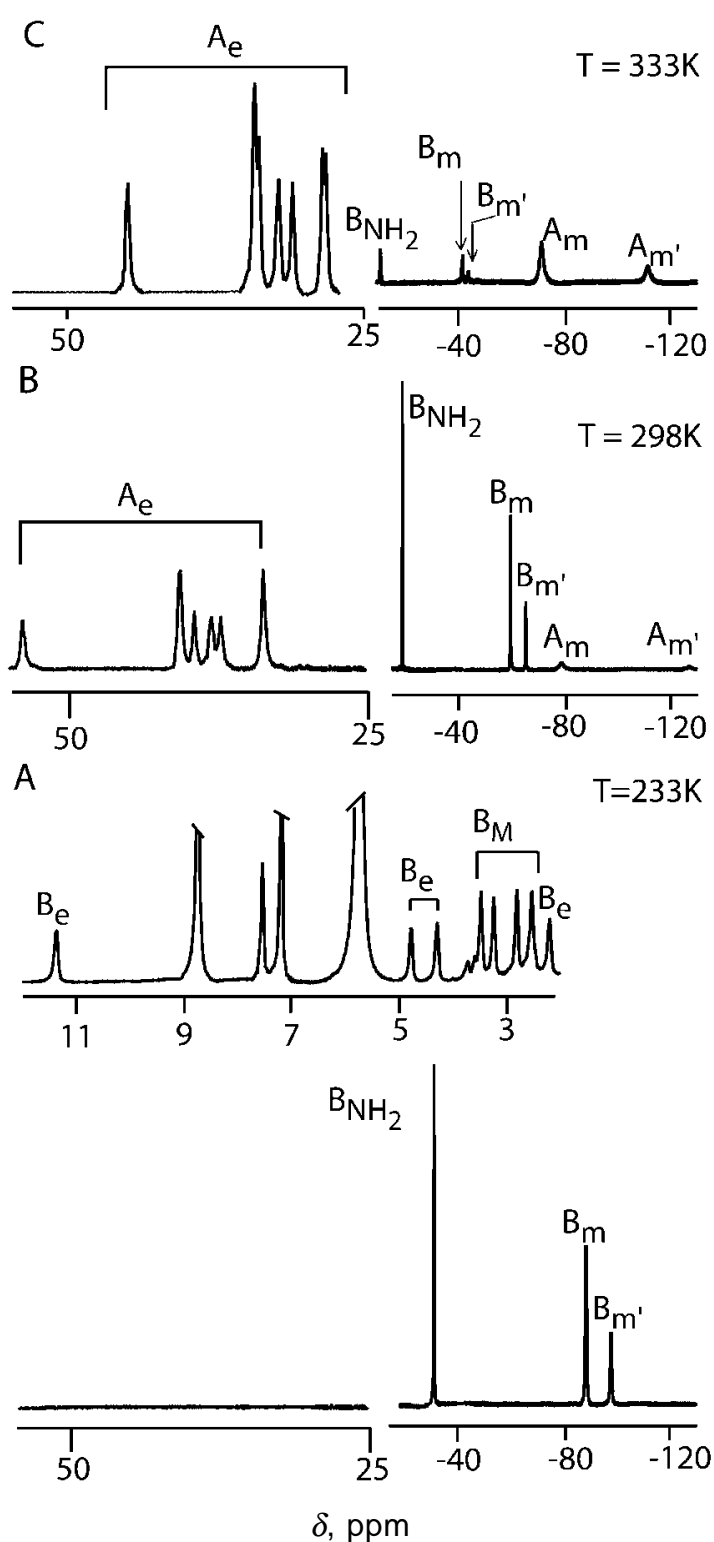

Figure 9. $500 \mathrm{MHz}{ }^{1} \mathrm{H} \mathrm{NMR}$ spectra of $\left[\mathrm{ClFe}^{\mathrm{III}}\right.$ (meso$\mathrm{NH}_{2}$-OEP)] in pyridine- $d_{5}$ at $\mathrm{A}, 233 \mathrm{~K} ; \mathrm{B}, 298 \mathrm{~K}$; and $\mathrm{C}$, $333 \mathrm{~K}$. Resonances due to [(py $)_{n} \mathrm{ClFe}^{\mathrm{III}}\left(\right.$ meso- $\left.\left.\mathrm{NH}_{2}-\mathrm{OEP}\right)\right]$ are labelled $\mathbf{A}$, while those of $\left[(\text { py })_{2} \mathrm{Fe}^{\text {III }}\left(\text { meso- } \mathrm{NH}_{2} \mathrm{OEP}\right)\right]^{+}$ are labelled B. Subscripts $\mathrm{m}$ and $\mathrm{m}^{\prime}$ denote the meso protons, $\mathrm{M}$ denotes the methyl protons, e denotes the methylene protons, and $\mathrm{NH}_{2}$ denotes the amino protons. Taken from ref. [16]. 

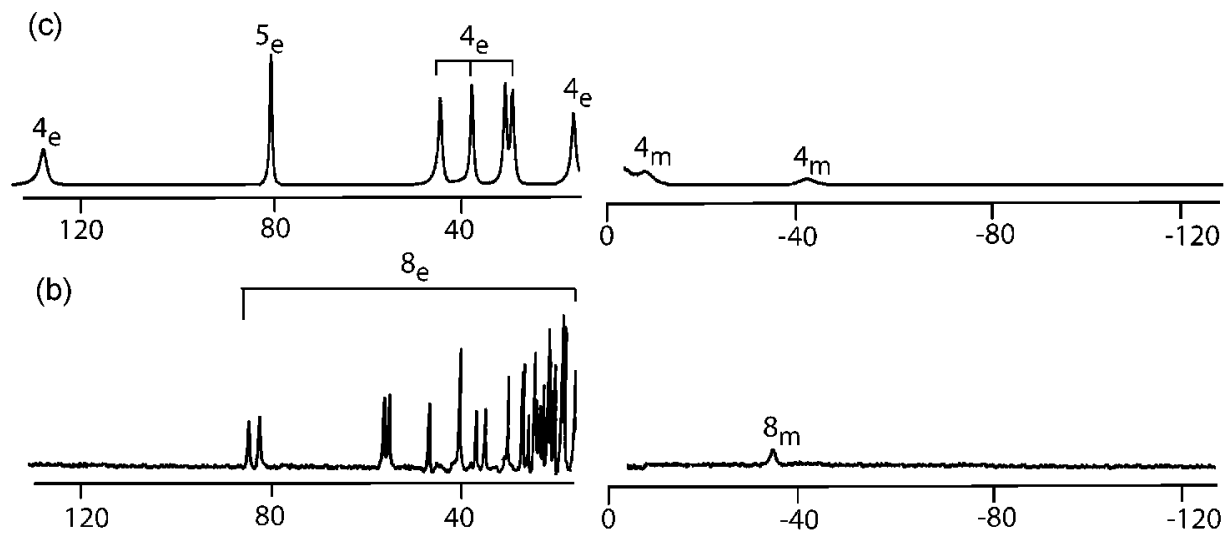

(a)

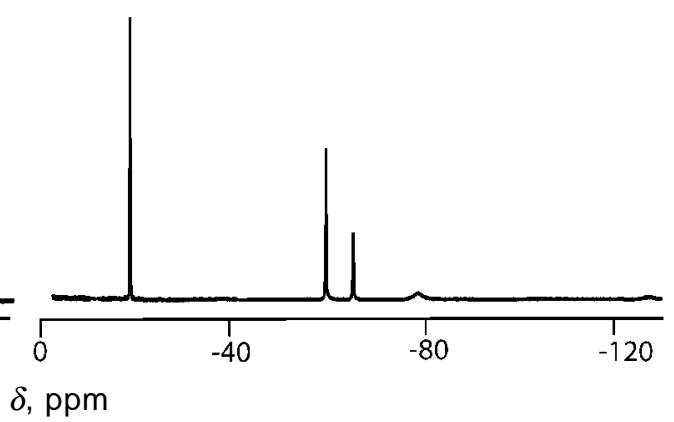

Figure 10. $500 \mathrm{MHz}{ }^{1} \mathrm{H} \mathrm{NMR}$ spectra of the reaction of $\left[\mathrm{ClFe}^{\mathrm{III}}\left(\right.\right.$ meso- $\left.\left.\mathrm{NH}_{2}-\mathrm{OEP}\right)\right]$ in pyridine- $d_{5}$ at $25^{\circ} \mathrm{C}$ : (a) before addition of dioxygen; (b) $12 \mathrm{~h}$ after the addition of dioxygen; (c) one week after the addition of dioxygen. The numbers in the figure represent the complexes shown in scheme 3. Subscripts $m$ denote the meso protons, e denotes the methylene protons. Taken from ref. [16].

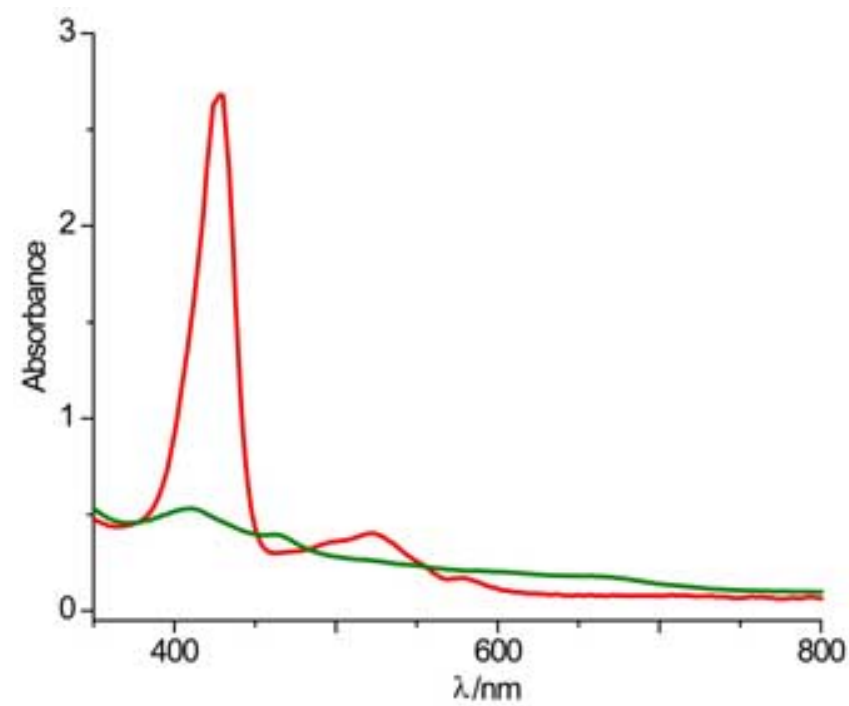

Figure 11. UV/vis absorption spectra of a pyridine solution of $\left[(\mathrm{py})_{2} \mathrm{Fe}^{\mathrm{II}}\left(\right.\right.$ meso- $\left.\left.\mathrm{H}_{2} \mathrm{~N}-\mathrm{OEP}\right)\right]$ before (red line) and immediately after (green line) exposure to dioxygen. Taken from ref. [15].

$\left.\left.\mathrm{O}_{2} \mathrm{~N}-\mathrm{OEP}\right)\right]$. In $\left[\mathrm{ClFe}^{\mathrm{III}}\left(\right.\right.$ meso- $\left.\left.\mathrm{NH}_{2}-\mathrm{OEP}\right)\right]$ the porphyrin core assumes a ruf conformation rather than the dom conformation found for the parent, $\left[\mathrm{ClFe}^{\mathrm{III}}\right.$ (OEP)]. ${ }^{16}$ The largest displacements occur in the vicinity of the amino group.

${ }^{1} \mathrm{H}$ NMR spectra in $\mathrm{CDCl}_{3}$ for $\left[\mathrm{ClFe}^{\mathrm{III}}\right.$ (meso- $\mathrm{NH}_{2}-$ OEP)] is shown in figure $8 .{ }^{16}$ As expected, there are two resonances in the far up field region with a $2: 1$ intensity ratio that are assigned to the meso protons, and seven resonances, one with twice the intensity of the other, are assigned to the methylene protons. The resonance at $14 \mathrm{ppm}$ is assigned to the amino protons. Two resonances with a $3: 1$ relative intensity ratio are assigned to the methyl protons.

${ }^{1} \mathrm{H}$ NMR spectrum of $\left[\mathrm{ClFe}^{\mathrm{III}}\right.$ (meso- $\left.\left.\mathrm{NH}_{2}-\mathrm{OEP}\right)\right]$ in pyridine- $d_{5}$ solution looks different and studied at three different temperatures as shown in figure $9 .^{16}$ It has been found that the spectrum shows the presence of two species $\mathbf{A}$ and $\mathbf{B}$, in which the relative intensities changes with temperature since they are in dynamic equilibriums. At high temperature, A dominates, while at low temperature, $\mathbf{B}$ is the major species. Eight methylene resonances and two meso resonance of up field shifts for $\mathbf{A}$ are observed clearly at high temperature and the spectral pattern is best 


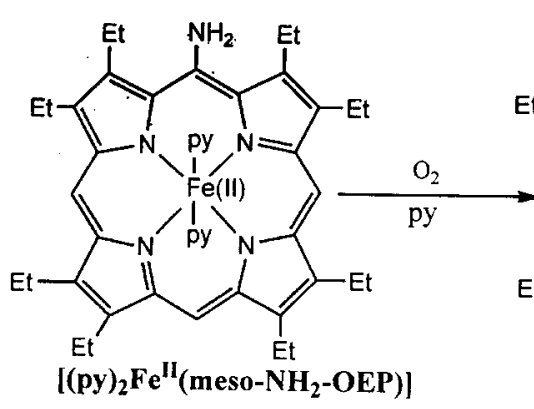

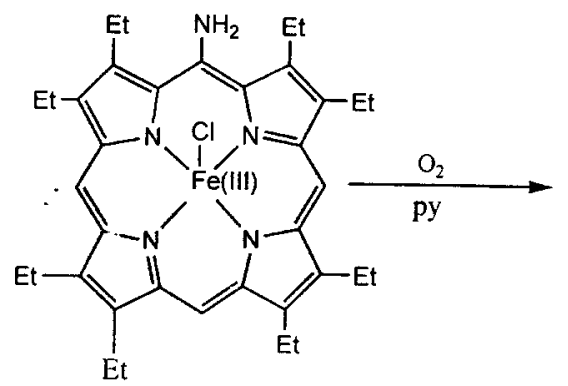

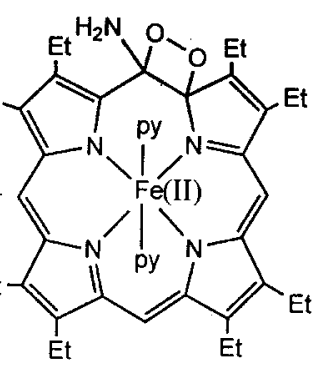

Or

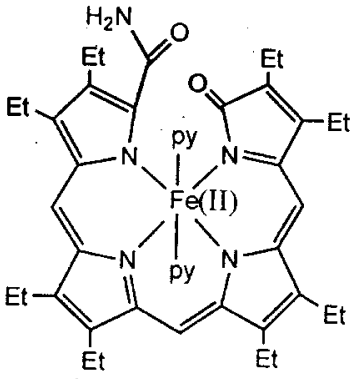

Green intermediate, 7

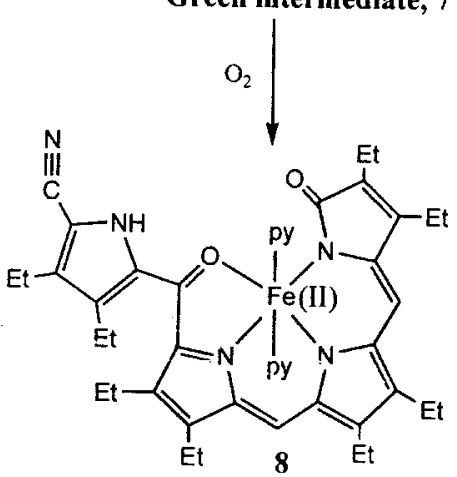

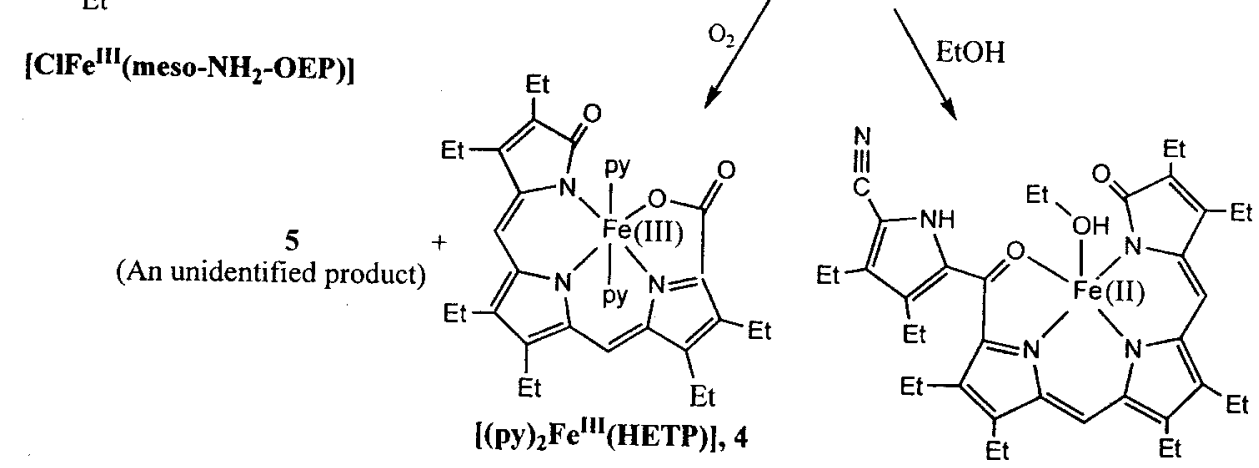

Scheme 3.

explained as high-spin $\left[(\mathrm{py})_{n} \mathrm{ClFe}^{\mathrm{III}}\left(\right.\right.$ meso- $\left.\left.\mathrm{NH}_{2}-\mathrm{OEP}\right)\right]$ where $n=0$ or 1 . In case of $\mathbf{B}$ two resonances at -88.5 and -97.9 ppm with $2: 1$ intensity ratio are assigned to the meso protons, while the resonance at -30.9 is assigned to the meso- $\mathrm{NH}_{2}$ protons. Four equally intense resonances at $11 \cdot 3,4 \cdot 8,4 \cdot 3$, and $2 \cdot 2 \mathrm{ppm}$ are assigned to the methylene resonances and also four equally intense resonances at $3 \cdot 5,3 \cdot 2$, $2 \cdot 8$, and $2.5 \mathrm{ppm}$ are assigned to the methyl resonances as seen in the inset to trace A. This NMR spectral pattern and the positions of signals therein indicates that $\mathbf{B}$ is a six-coordinate low-spin complex and formulated as $\left[(\mathrm{py})_{2} \mathrm{Fe}^{\mathrm{III}}\left(\right.\right.$ meso- $\left.\left.\mathrm{NH}_{2}-\mathrm{OEP}\right)\right] \mathrm{Cl} .{ }^{16}$

\subsection{Reactions with dioxygen}

Chloroform solutions of $\left[\mathrm{ClFe}^{\mathrm{III}}\left(\right.\right.$ meso- $\left.\left.\mathrm{NH}_{2}-\mathrm{OEP}\right)\right]$ are very stable in dioxygen atmosphere whereas its pyridine solutions are unstable in the presence of dioxygen and the progress of the reaction are demonstrated via ${ }^{1} \mathrm{H}$ NMR spectroscopy as shown in figure $10 .{ }^{16}$ Trace A represents the spectrum before the addition of dioxygen, whereas trace $\mathrm{B}$ shows the spectrum $12 \mathrm{~h}$ after the addition of dioxygen. During this time, the resonances of $\left[(\mathrm{py})_{n} \mathrm{ClFe}{ }^{\mathrm{III}}\left(\right.\right.$ meso- $\left.\left.\mathrm{NH}_{2}-\mathrm{OEP}\right)\right]$ $(n=0,1)$ and $\left[(\mathrm{py})_{2} \mathrm{Fe}^{\mathrm{III}}\left(\right.\right.$ meso- $\left.\left.\mathrm{NH}_{2}-\mathrm{OEP}\right)\right] \mathrm{Cl}$ vanish completely while a set of new resonances develop. The reactive intermediate have been isolated carefully and characterized as an open-chain tetrapyrrole complex 8 as shown in scheme 3. Further exposure to dioxygen over a period of one week shows the completely new resonances which are very similar to the spectrum seen in trace $\mathrm{C}$ of figure $2 .{ }^{16}$ In trace $\mathrm{C}$, two sets of resonances have been identified. Those labelled 4 are due to the presence of $\left.[\mathrm{py})_{2} \mathrm{Fe}^{\mathrm{III}}(\mathrm{HETP})\right]$, 4 , and the prominent resonance at $81.2 \mathrm{ppm}$ signals 
occur due to another unidentified species $\mathbf{5}$, which is also found in the oxidation process of $\left[(\mathrm{py})_{2} \mathrm{Fe}^{\mathrm{III}}\right.$ (OEPO)] but as a minor product only.
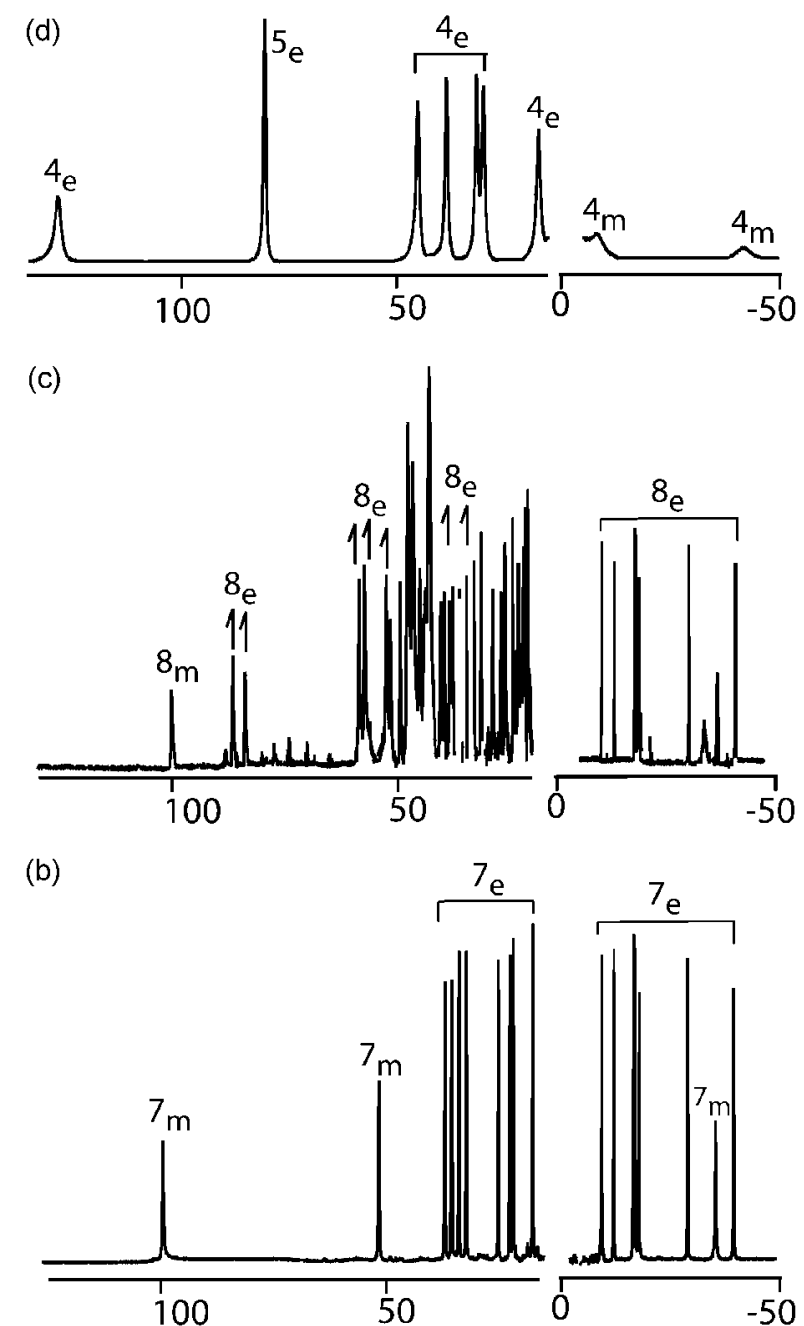

(a)

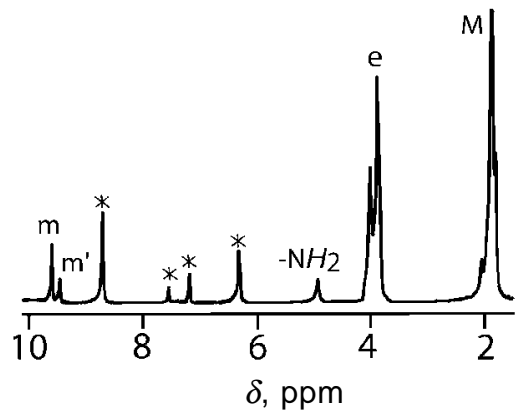

Figure 12. $500 \mathrm{MHz}{ }^{1} \mathrm{H}$ NMR spectra of the reaction of $\left[(\mathrm{py})_{2} \mathrm{Fe}^{\mathrm{II}}\left(\right.\right.$ meso- $\left.\left.\mathrm{NH}_{2}-\mathrm{OEP}\right)\right]$ in pyridine- $d_{5}$ at $25^{\circ} \mathrm{C}(\mathbf{a})$ before addition of dioxygen; (b) 2 min after the addition of dioxygen; (c) 20 min after the addition of dioxygen; (d) one week after the addition of dioxygen. Numbers in the figure represent the complexes shown in scheme 3. Subscripts $\mathrm{m}$ and $\mathrm{m}^{\prime}$ denote the meso protons, $\mathrm{M}$ denotes the methyl protons, e denotes the methylene protons, and $\mathrm{NH}_{2}$ denotes the amino protons. Taken from ref. [16].
Addition of zinc amalgam to a pyridine solution of $\left[\mathrm{ClFe}^{\mathrm{III}}\right.$ (meso- $\mathrm{NH}_{2}$-OEP) $]$ under dinitrogen atmosphere produces a bright-red diamagnetic solution within a minute and air-sensitive $\left[(\mathrm{py})_{2} \mathrm{Fe}^{\mathrm{II}}\right.$ (meso$\mathrm{NH}_{2}$-OEP)] have been isolated from the solution. Exposure of the red pyridine solution to air immediately changes the color to green, whereas $\left[(\mathrm{py})_{2} \mathrm{Fe}^{\mathrm{II}}(\mathrm{OEP})\right]$, under identical conditions, remains unchanged. ${ }^{15,16}$ Relevant UV/vis absorption spectra are shown in figure 11, where the drop in the intensity of the characteristic Soret band at $420 \mathrm{~nm}$ indicates that the porphyrin has undergone a ring-opening process. ${ }^{15}$ Figure 12 shows the effects of dioxygen addition on the ${ }^{1} \mathrm{H}$ NMR spectra of a solution of $\left[(\mathrm{py})_{2} \mathrm{Fe}^{\mathrm{II}}\right.$ (meso$\mathrm{NH}_{2}$-OEP)] in pyridine- $d_{5}$ at $298 \mathrm{~K}^{16}$ Trace A shows the spectrum before the addition of dioxygen. Upon exposure to dioxygen, the spectrum of the complex transformed immediately showing completely new spectrum as shown in trace $B$ of figure 12. The overall pattern of resonances with 16 methylene

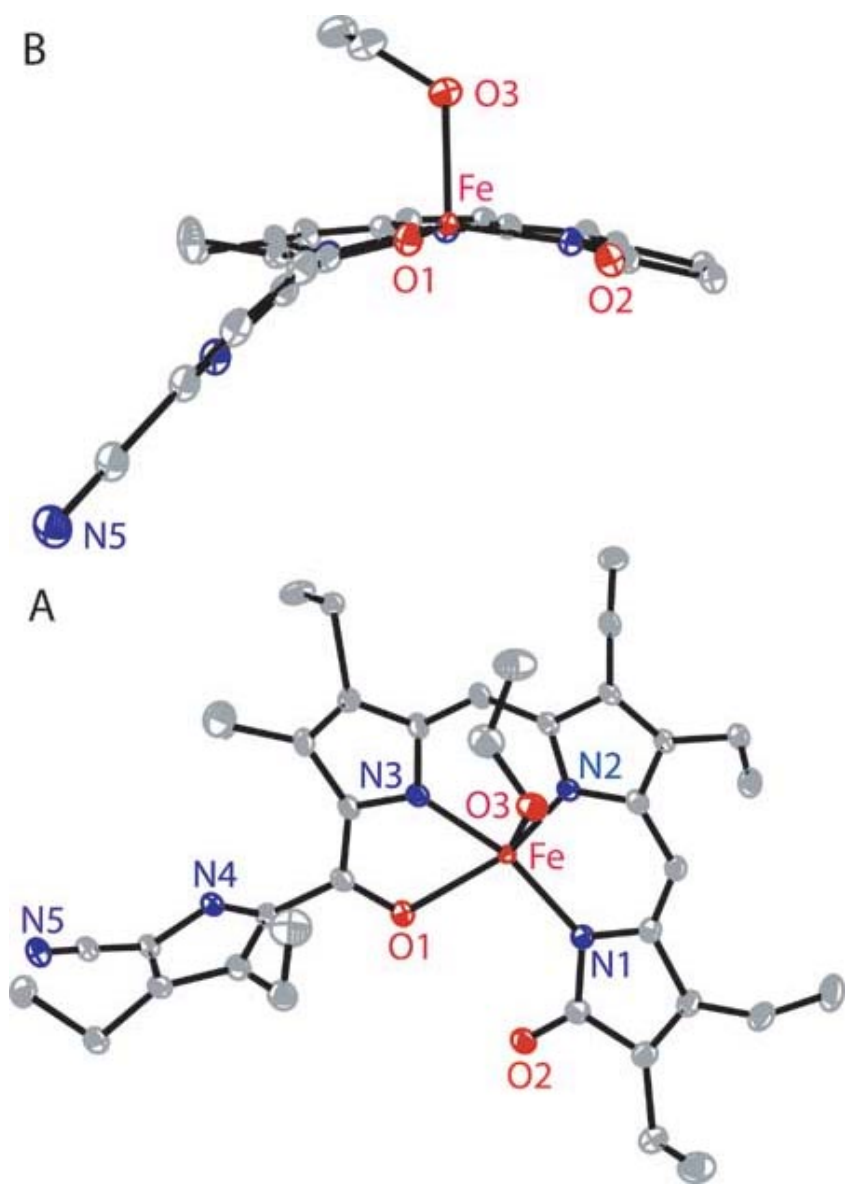

Figure 13. Two perspective views of the open chain tetrapyrrole complex $\mathbf{8}$ showing $30 \%$ thermal contours. For clarity the ethyl groups have been removed in part B. Taken from ref. [16]. 
(b)

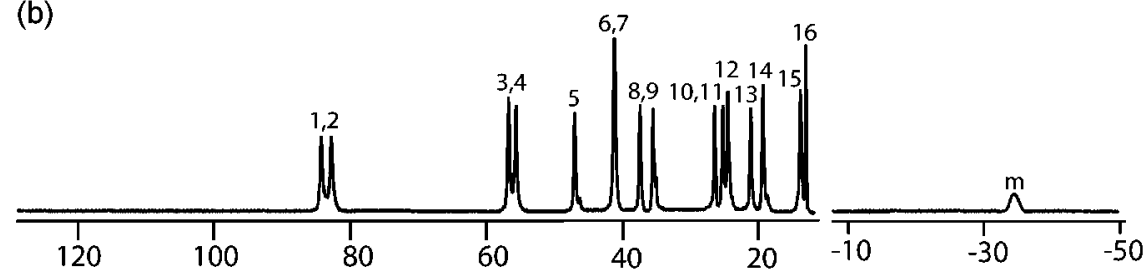

(a)

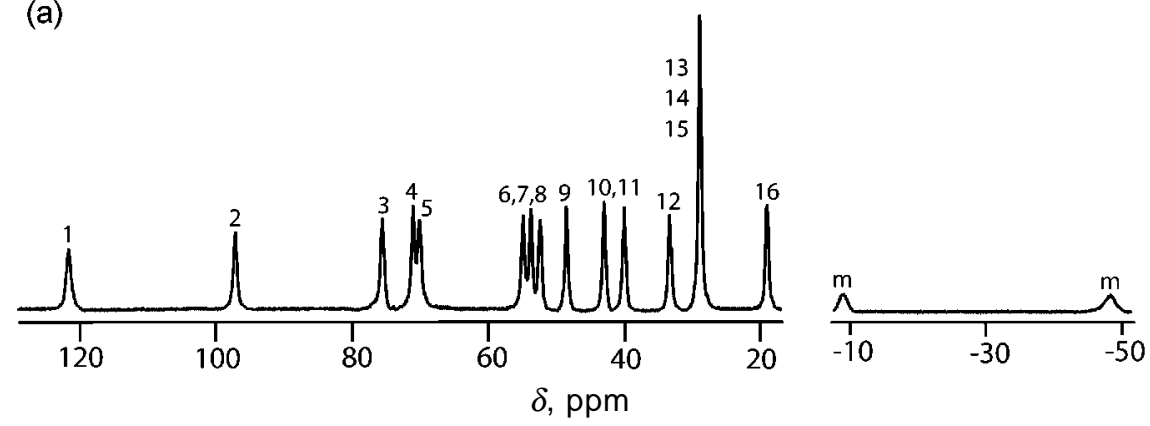

Figure 14. Portions of the $500 \mathrm{MHz}{ }^{1} \mathrm{H}$ NMR spectrum of the open chain tetrapyrrole complex 8 in pyridine- $d_{5}$. at: (a) $245 \mathrm{~K}$ and (b) $298 \mathrm{~K}$. Taken from ref. [16].
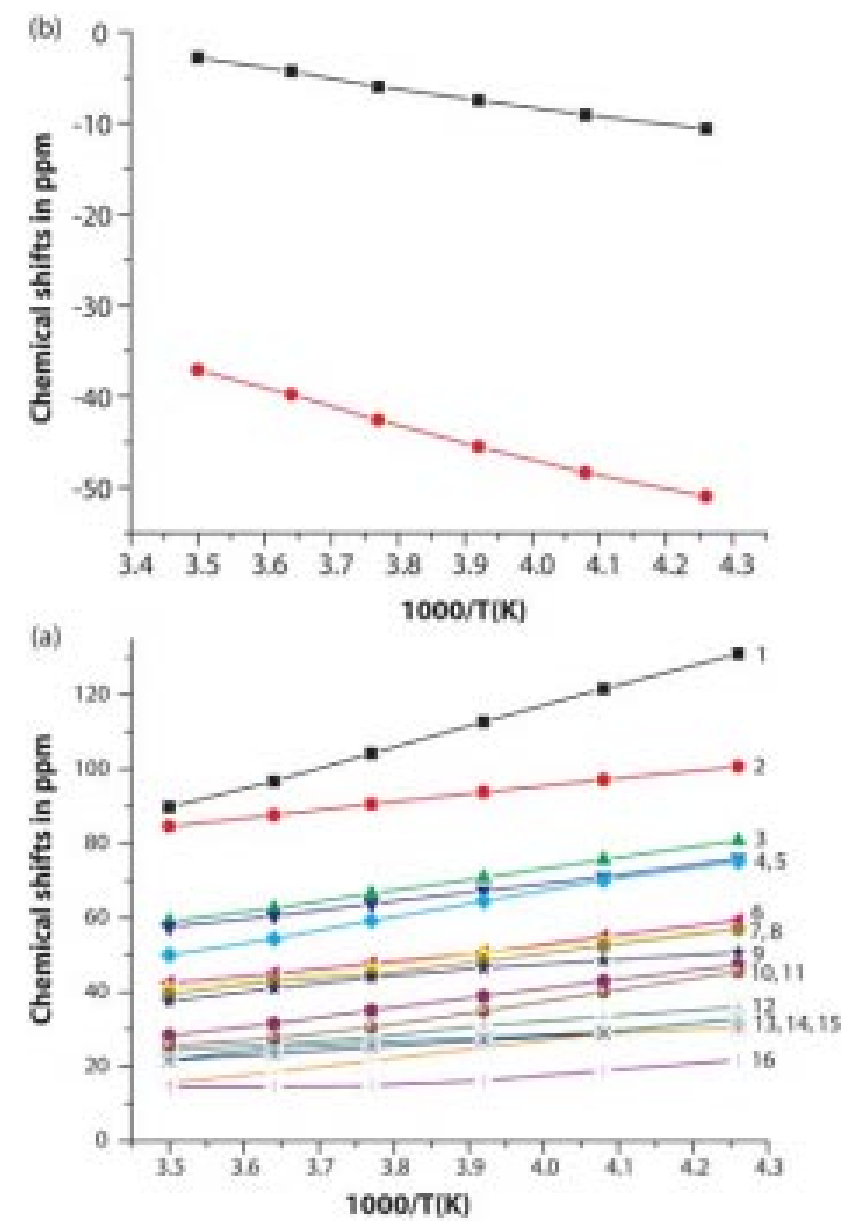

Figure 15. A plot of chemical shift versus $1 / T$ for the open-chain tetrapyrrole complex 8; (A) for methylene resonances and (B) for the meso resonances. The numbers $1,2,3 \ldots$ etc. are the same numbers used to mark the signals in figure 14. Taken from ref. [16]. resonances and three equally intense meso resonances indicates the significant lowering of the symmetry of the porphyrin and is consistent with the formation of either of the two hypothetical intermediate, 7, as shown in scheme 3. Attempts to isolate 7 from solution by precipitation have not been successful because of its very high reactivity. On further exposure to dioxygen it changes again and after $20 \mathrm{~min}$ produces a spectrum as in trace $\mathrm{C}$. The resonances of the open-chain tetrapyrrole complex $\mathbf{8}$ are clearly present along with others. Further exposure to dioxygen over a period of a week produces the spectrum shown in trace D of figure 12. Resonances due to $\left[(\mathrm{py})_{2} \mathrm{Fe}^{\mathrm{III}}(\mathrm{HETP})\right], \mathbf{4}$, are clearly observed as well as the resonance at $81 \cdot 2 \mathrm{ppm}$ due to 5 .

In pyridine solution, the iron(II) complex $\left[(\mathrm{py})_{2}\right.$ $\mathrm{Fe}^{\mathrm{II}}$ (meso- $\left.\left.\mathrm{NH}_{2}-\mathrm{OEP}\right)\right]$ consumes dioxygen more rapidly than the iron(III) complex, $\left[\mathrm{ClFe}^{\mathrm{III}}\right.$ (meso- $\mathrm{NH}_{2}-$ $\mathrm{OEP})]$. The reaction of $\left[(\mathrm{py})_{2} \mathrm{Fe}^{\mathrm{II}}\left(\right.\right.$ meso $\left.\left.-\mathrm{NH}_{2}-\mathrm{OEP}\right)\right]$ with dioxygen initially produces the green radical $\mathbf{7}$, which has not been observed from the oxidation of iron(III) complex of $\left[\mathrm{ClFe}^{\mathrm{III}}\left(\right.\right.$ meso- $\left.\left.\mathrm{NH}_{2}-\mathrm{OEP}\right)\right]$ in pyridine. Both $\left[(\mathrm{py})_{2} \mathrm{Fe}^{\mathrm{II}}\left(\right.\right.$ meso- $\left.\left.\mathrm{NH}_{2}-\mathrm{OEP}\right)\right]$ and $\left[\mathrm{ClFe}{ }^{\mathrm{III}}\right.$ (meso- $\left.\left.\mathrm{NH}_{2}-\mathrm{OEP}\right)\right]$ react with dioxygen in pyridine to produce the open-chain tetrapyrrole complex 8. Addition of ethanol to the solution of $\mathbf{8}$ and subsequent slow evaporation gives the single crystals suitable for X-ray structure determination and the perspective view is shown in figure $13 .{ }^{16}$ Portions of the ${ }^{1} \mathrm{H}$ NMR spectrum of $\mathbf{8}$ dissolved in pyridine- $d_{5}$ are shown in figure 14 in which trace $\mathrm{A}$ 
shows the spectrum at $245 \mathrm{~K}$, while trace B shows the spectrum at $298 \mathrm{~K} .{ }^{16}$ Since there is an asymmetric carbon at the meso carbon $\mathrm{C} 15$, each methylene group is diastereotopic. Thus sixteen methylene resonances from eight chemically distinct ethyl groups are observed in the ${ }^{1} \mathrm{H}$ NMR spectrum which is consistent with the solid state structure of the complex 8. Two meso hydrogen resonances have been observed at -9 and $-48 \mathrm{ppm}$ in the spectrum obtained at $245 \mathrm{~K}$ but not in $298 \mathrm{~K}$, since they move downfield upon warming and a Curie plot of the chemical shifts of the meso and methylene protons of $\mathbf{8}$ are shown in the figure $15 .^{16}$

\section{Degradation pathways}

The ${ }^{1} \mathrm{H}$ NMR spectrum shown in trace $\mathrm{C}$ of figure 10 and trace $\mathrm{D}$ of figure 12 shows that oxidation of either $\left[\mathrm{ClFe}^{\mathrm{III}}\left(\right.\right.$ meso- $\mathrm{NH}_{2}$-OEP) $]$ or $\left[(\mathrm{py})_{2} \mathrm{Fe}^{\mathrm{II}}\right.$ (meso$\mathrm{NH}_{2}$ OEP)] in pyridine eventually results in the formation of not only the same mixture of complexes $\mathbf{4}$ and $\mathbf{5}$, but also almost in the same ratio. It was found that $\mathbf{4}$ and $\mathbf{5}$ are also formed during the oxidation of $\left[(\mathrm{py})_{2} \mathrm{Fe}^{\mathrm{III}}(\mathrm{OEPO})\right]$, but the relative amount of $\mathbf{5}$ formed is much smaller than it is in the oxidation of the amino-substituted species. ${ }^{16}$ Schemes 2 and 3 show the schematic overview of the ring-cleavage process for both the system.

While chloroform solutions of $\left[\mathrm{ClFe}{ }^{\mathrm{III}}\right.$ (meso- $\mathrm{NH}_{2}-$ OEP)] are very stable in dioxygen atmosphere, their pyridine solutions are very reactive undergoing the ring-cleavage process. It has also been observed that $\left[\mathrm{ClFe}^{\mathrm{III}}\right.$ (meso- $\left.\left.\mathrm{NH}_{2}-\mathrm{OEP}\right)\right]$ in dichloromethane solutions containing an excess of $\mathrm{N}$-methyl imidazole undergoes similar oxidation upon exposure to dioxygen. ${ }^{16}$ In case of $\left[(\mathrm{py})_{2} \mathrm{Fe}^{\mathrm{III}}(\mathrm{OEPO})\right]$, it was found that upon changing the axial ligand from pyridine to 2,6-xylyl isocyanide, the oxidation reaction does not go beyond verdoheme label. ${ }^{10-12}$ It clearly

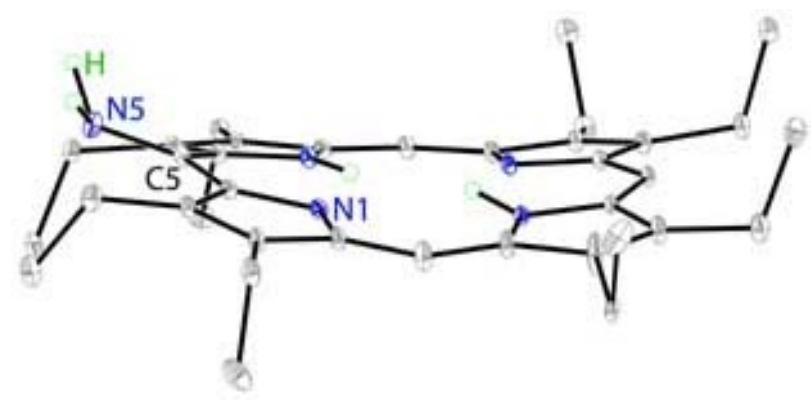

Figure 16. A perspective view of meso- $\mathrm{NH}_{2}-\mathrm{OEPH}_{2}$ showing $30 \%$ thermal contours. Taken from ref. [17]. shows that axial ligation plays an very important role in controlling the reactivity of these synthetic heme.

Figure 7 shows the largest out-of-plane displacement occurs in the vicinity of amino group in case of $\left[\mathrm{ClFe}{ }^{\mathrm{III}}\right.$ (meso- $\left.\left.\mathrm{NH}_{2}-\mathrm{OEP}\right)\right]$. To investigate the role of
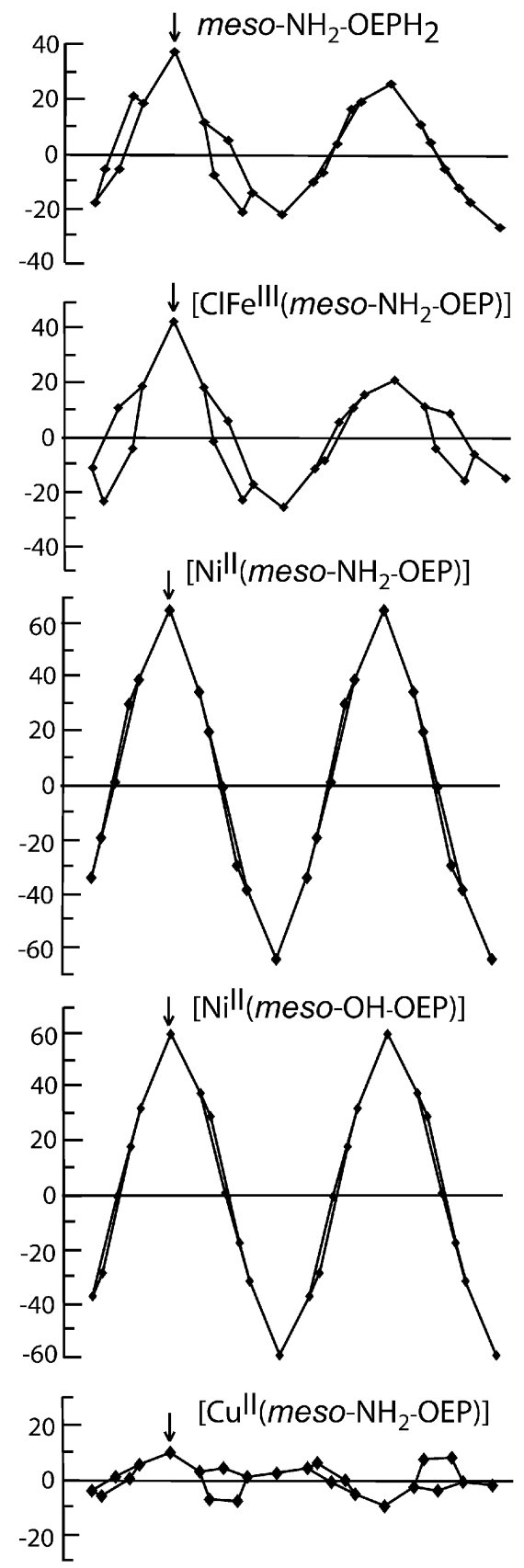

Figure 17. Out-of-plane displacements (in units of $0.01 \AA$ ) for the porphyrin core atoms from the mean plane of the porphyrin as shown at the top Meso-substituents are attached to the carbon atoms denoted by arrows. Taken from ref. [17]. 
porphyrin geometry on ring cleavage process, the free ligand meso- $\mathrm{NH}_{2}-\mathrm{OEPH}_{2}$ was also synthesized and the X-ray structure of the molecule is shown in figure $16 .{ }^{17}$ Figure 17 shows a comparison of the out-of-plane displacements (in units of $0.01 \AA$ ) of the core atoms of meso- $\mathrm{NH}_{2}-\mathrm{OEPH}_{2}$ with several other relevant porphyrins. It is found that the out-ofplane displacements for meso- $\mathrm{NH}_{2}-\mathrm{OEPH}_{2}$ are remarkably very similar to those observed for $\left[\mathrm{ClFe}^{\mathrm{III}}\left(\right.\right.$ meso- $\mathrm{NH}_{2}$-OEP) $]$. It is been also found that $\left[\mathrm{Cu}^{\mathrm{II}}\left(\right.\right.$ meso- $\left.\left.\mathrm{NH}_{2}-\mathrm{OEP}\right)\right]$ assumes a nearly planar geometry as shown in figure $18,{ }^{17}$ while $\left[\mathrm{Ni}^{\mathrm{II}}\right.$ (meso$\mathrm{NH}_{2}$-OEP)] in figure 19 shows highly non-planar geometry. However pyridine solutions of none of these react with dioxygen. ${ }^{17}$ However, $\left[\mathrm{Ni}^{\mathrm{II}}\right.$ (mesoHO-OEP)] when dissolves in pyridine readily oxidized by dioxygen to form the air-stable radical, $\left[(p y)_{2} \mathrm{Ni}^{\mathrm{II}}\right.$ (OEPO.)], which has been isolated and fully characterized. ${ }^{18}$ In this case also porphyrin ligand is highly nonplaner. Thus it has been found

B

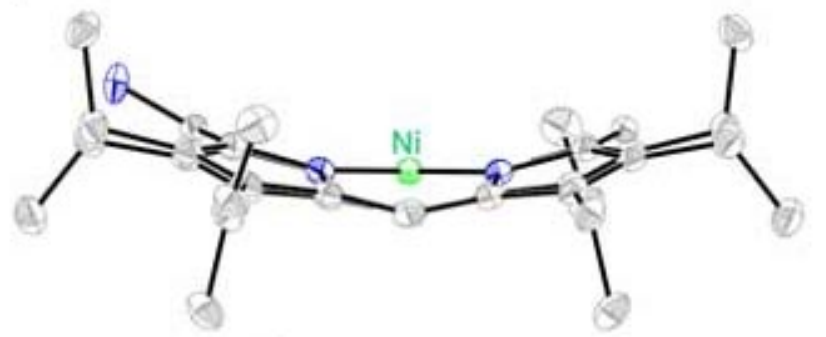

A

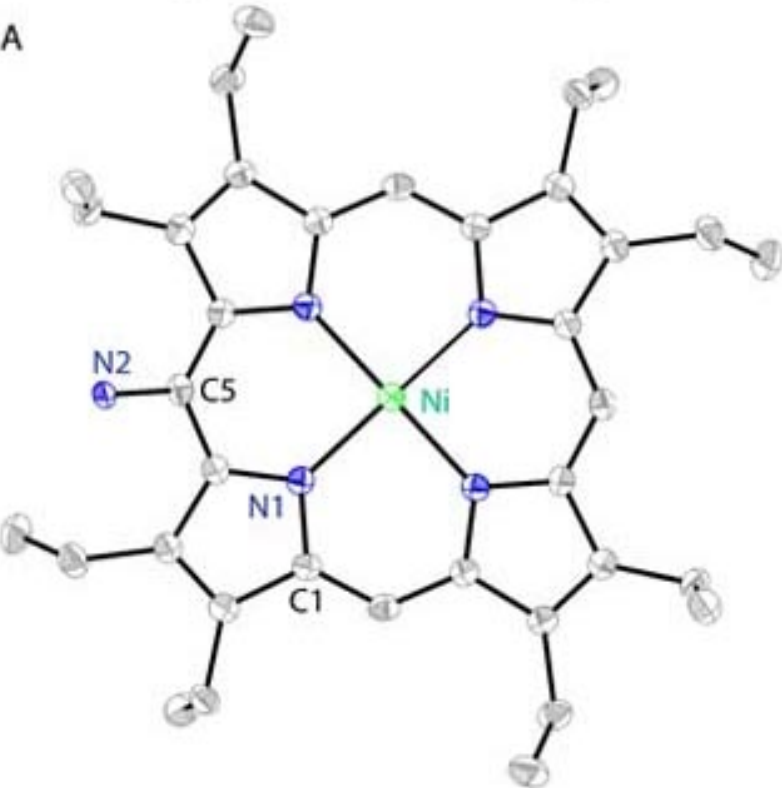

Figure 18. Two perspective views of $\left[\mathrm{Ni}^{\mathrm{II}}\left(\right.\right.$ meso- $-\mathrm{NH}_{2}-$ OEP)] with $30 \%$ thermal contours. Taken from ref. [17]. that meso- $\mathrm{NH}_{2}-\mathrm{OEPH}_{2}$ and its complexes can assume a variety of structures with varying degrees of planarity and that the amino group itself does not impose a particular geometry on the macrocycle. It also shows that, most probably, porphyrin geometry has nothing to do with the ring-cleavage process.

\section{Conclusions}

Porphyrin ligands are highly resistant to oxidation and are utilized to carry out a variety of biological processes in which highly oxidized iron complexes are formed. However heme oxygenase is used by Nature to destroy excess heme. The process involves initial meso hydroxylation of the heme to form a reactive iron oxophlorin which is a fundamental step in the heme-degradation process. Thus while pyridine solutions of model $\mathrm{Fe}(\mathrm{II})$ hemes, such as $\left[(\mathrm{py})_{2} \mathrm{Fe}^{\mathrm{II}}\right.$ $(\mathrm{OEP})]$ remain unchanged upon exposure of dioxygen over a period of many hours, it has been found that the corresponding model meso-hydroxylated
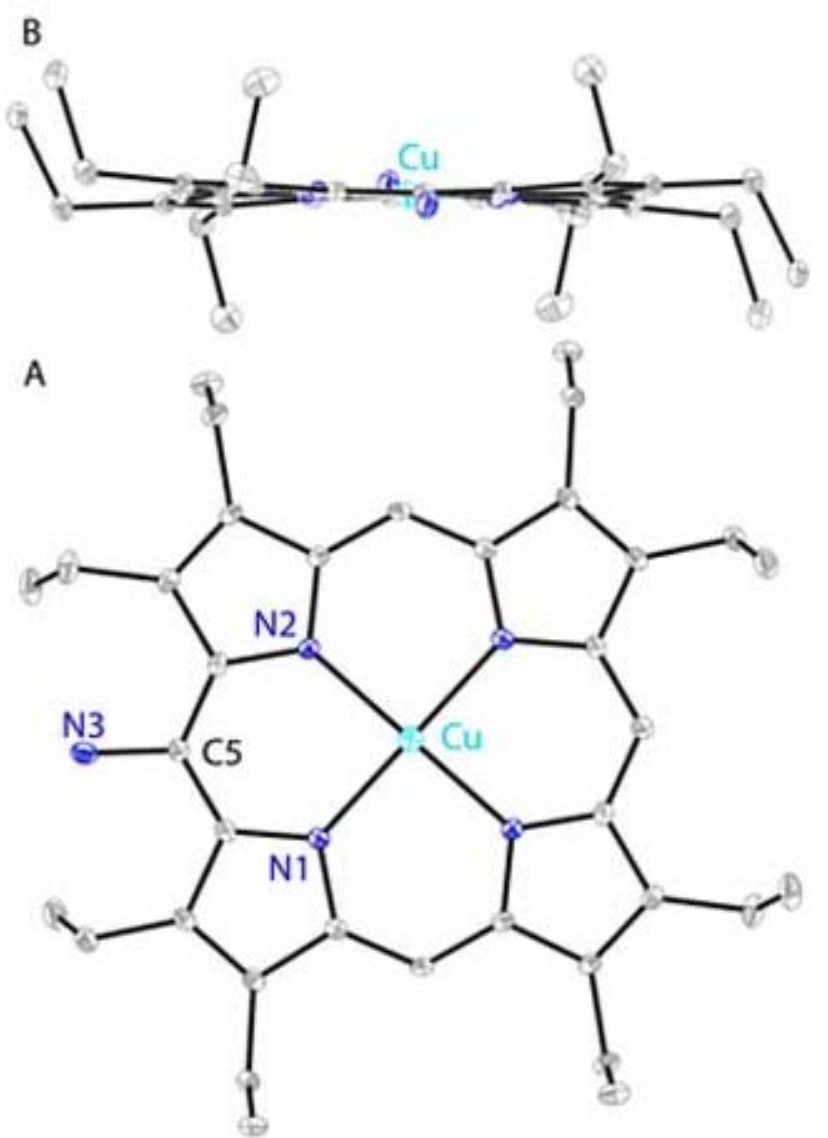

Figure 19. Two perspective views of $\left[\mathrm{Cu}^{\mathrm{II}}\left(\right.\right.$ meso- $-\mathrm{NH}_{2}-$ OEP)] with $30 \%$ thermal contours. Taken from ref. [17]. 
heme $\left[(\mathrm{py})_{2} \mathrm{Fe}^{\mathrm{II}}(\mathrm{OEPOH})\right]$, or meso-amino heme $\left[(\text { py })_{2} \mathrm{Fe}^{\mathrm{II}}\right.$ (meso- $\left.\left.\mathrm{NH}_{2}-\mathrm{OEP}\right)\right]$ instantaneously react with dioxygen undergoing heme degradation. On the other hand, their iron(III) analogs, [(py $\left.\left.)_{2} \mathrm{Fe}^{\mathrm{III}} \mathrm{OEPO}\right)\right]$ and $\left[(\mathrm{py})_{2} \mathrm{Fe}^{\mathrm{III}}\right.$ (meso- $\mathrm{NH}_{2}$-OEP) $]$ also react with dioxygen in the similar ways. However in all these model cases, the final degradation products are the same, i.e. $\mathbf{4}$ and $\mathbf{5}$, although their ratio varies. The relative amounts of $\mathbf{5}$ formed in the oxidation of $\left[(\mathrm{py})_{2} \mathrm{Fe}^{\mathrm{II}}(\mathrm{OEPOH})\right]$ or $\left[(\mathrm{py})_{2} \mathrm{Fe}^{\mathrm{III}}(\mathrm{OEPO})\right]$ are much smaller than in the oxidations of $\left[(\mathrm{py})_{2} \mathrm{Fe}^{\mathrm{II}}\right.$ (meso$\left.\left.\mathrm{NH}_{2}-\mathrm{OEP}\right)\right]$ or $\left[(\mathrm{py})_{2} \mathrm{Fe}^{\mathrm{III}}\left(\right.\right.$ meso- $\left.\left.\mathrm{NH}_{2}-\mathrm{OEP}\right)\right]$. The result also shows that, in both cases, the reaction undergo similar transformations although rate of the oxidation is much faster in case of meso-hydroxylated system. Most probably ring-cleavage requires an electron-donating group such as $\mathrm{OH}$ or $\mathrm{NH}_{2}$ at one of the meso position.

Five-coordinate $\left[\mathrm{ClFe}^{\mathrm{III}}\left(\right.\right.$ meso- $\left.\left.\mathrm{NH}_{2}-\mathrm{OEP}\right)\right]$ is unreactive toward dioxygen when dissolved in non-coordinating solvents such as chloroform, but heme degradation starts immediately in the presence axial ligands such as pyridine, 1-methyl imidazole etc., which clearly shows the involvements of the axial ligands in the degradation process although the exact nature is still unknown. Similar observations are obtained in case of meso-hydroxylated heme also.

It has been seen from figures 7 and 17 that meso$\mathrm{NH}_{2}-\mathrm{OEPH}_{2}$ and its complexes can assume a variety of structures with varying degrees of planarity and that the amino group itself does not impose a particular geometry on the macrocycle. Most probably, porphyrin geometry has nothing to do with the ringcleavage process of the molecules.

While pyridine solutions of meso- $\mathrm{NH}_{2}-\mathrm{OEPH}_{2}$, $\left[\mathrm{Ni}^{\mathrm{II}}\left(\right.\right.$ meso- $\left.\left.\mathrm{NH}_{2}-\mathrm{OEP}\right)\right]$ and $\left[\mathrm{Cu}^{\mathrm{II}}\left(\right.\right.$ meso $\left.\left.-\mathrm{NH}_{2}-\mathrm{OEP}\right)\right]$ do not undergo ring cleavage upon exposed to dioxygen, the pyridine solutions of $\left[(\mathrm{py})_{2} \mathrm{Fe}^{\mathrm{II}}\right.$ (meso$\mathrm{NH}_{2}$-OEP $\left.)\right]$ and $\left[(\mathrm{py})_{2} \mathrm{Fe}^{\mathrm{III}}\left(\right.\right.$ meso- $\left.\left.\mathrm{NH}_{2}-\mathrm{OEP}\right)\right]$ are very reactive. It is thus clear that the simple presence of meso amino-octaethylporphyrin as a ligand does not produce complexes that are necessarily susceptible to oxidation. Similar observations are also obtained in case of meso-hydroxylated heme. Thus, the metal definitely plays a crucial role which needs further investigation to identify.

\section{Acknowledgments}

The author sincerely thanks Professor Alan L Balch for providing all facilities and support during his stay at the University of California, Davis, USA. The author also thanks Professor Marilyn L Olmstead and Professor Latos-Grazùyn'ski for several discussions and help. The Department of Science and Technology, Govt. of India and Council of Scientific and Industrial Research, New Delhi are gratefully acknowledged for financial support.

\section{References}

1. Sono M, Roach M P, Coulte E D and Dawson J H 1996 Chem. Rev. 962841

2. Ortiz de Montellano P R and Auclair K 2003 In The porphyrin handbook (eds) K M Kadish, K M Smith and R Guilard (New York: Academic Press) vol. 12, pp 183-210

3. Maines M D 1992 Heme oxygenase: Clinical applications and functions (Boca Raton, FL: CRC Press)

4. Morse D and Choi M K 2002 Am. J. Respir. Cell. Biol. 278

5. Rivera M and Zeng Y 2005 J. Inorg. Biochem. 99337

6. Sakamoto H, Higashimoto Y, Hayashi S, Sugishima M, Fukuyama K, Palmer G and Noguchi M $2004 \mathrm{~J}$. Inorg. Biochem. 981223

7. Balch A L 2000 Coord. Chem. Rev. 200-202 349

8. Rath S P, Omstead M M and Balch A L 2006 Inorg. Chem. 456083

9. Balch A L, Koerner R, Latos-Grazynski L and Noll B C 1996 J. Am. Chem. Soc. 1182760

10. Rath S P, Omstead M M and Balch A L 2004 J. Am. Chem. Soc. 1266379

11. Rath S P, Olmstead M M and Balch A L 2004 Inorg. Chem. $\mathbf{4 3} 7648$

12. Rath S P, Olmstead M M and Balch A L 2004 Inorg. Chem. 436357

13. Rath S P, Koerner R, Omstead M M and Balch A L 2003 J. Am. Chem. Soc. 12511798

14. Rath S P, Olmstead M M, Latos-Grazùyn'ski L and Balch A L 2003 J. Am. Chem. Soc. 12512678

15. Kalish H, Lee $H$ M, Olmstead M M, LatosGrazùyn'ski L, Rath S P and Balch A L 2003 J. Am. Chem. Soc. 1254674

16. Rath S P, Kalish H, Latos-Grazùyn'ski L, Olmstead M M and Balch A L 2004 J. Am. Chem. Soc. 126646

17. Sprutta N, Rath S P, Olmstead M M and Balch A L 2005 Inorg. Chem. 441452

18. Balch A L, Noll B C, Phillips S L, Reid S M and Zovinka E P 1993 Inorg. Chem. 324730 